Digital Press Life Sciences

Preparation of Indigenous Lactic Acid Bacteria Starter Cultures for Large Scale Production of Fermented Milk

Tyas Utami, Amaralda Cindarbhumi, Marcella C. Khuangga, Endang S.

Rahayu, Muhammad Nur Cahyanto, Sri Nurfiyani and Eni Zulaichah

10th Asian Conference of Lactic Acid Bacteria

I Nengah Sujaya, Endang S. Rahayu, Tyas Utami (eds) 


\title{
Preparation of Indigenous Lactic Acid Bacteria Starter Cultures for Large Scale Production of Fermented Milk
}

\author{
Tyas Utami ${ }^{1, *}$, Amaralda Cindarbhumi ${ }^{1}$, Marcella C Khuangga ${ }^{1}$, Endang S Rahayu ${ }^{1}$, Muhammad Nur \\ Cahyanto $^{1}$, Sri Nurfiyani ${ }^{2}$, Eni Zulaichah ${ }^{2}$ \\ ${ }^{1}$ Department of Food and Agricultural Product Technology, Faculty of Agricultural Technology, Universitas Gadjah Mada, Jl Flora No \\ 1, Bulaksumur, Yogyakarta, Indonesia \\ PT Yummy Food Utama, Indonesia \\ *e-mail: tyas_utami@ugm.ac.id
}

\begin{abstract}
Lactobacillus plantarum Dad 13, an indigenous probiotic was examined its ability to be used as a single starter culture or mixed cultures with Streptococcus thermophilus Dad 11 for milk fermentation. Both cultures were isolated from dadih, a traditional fermented buffalo milk. The purposes of this study were to produce indigenous lactic acid bacteria starter cultures using halal growth medium and evaluate their application on large scale fermented milk production. The halal medium was developed using natural compounds such as sucrose, meat peptone, mung bean sprout extract, tomato extract, and young coconut water. Meat peptone was prepared by hydrolysis of halal meat using crude bromelain. Lactic acid bacteria were grown in the halal growth medium then harvested, frozen and freeze-dried. A single freeze-dried starter culture of L. plantarum Dad 13 and frozen mixed cultures of L. plantarum Dad 13 and S. thermophilus Dad 11 were prepared for production of fermented milk drink and yogurt respectively in industrial scale. The growth of these lactic acid bacteria in halal growth medium increased the viable cell to two log cycles $\left(10^{9} \mathrm{CFU} / \mathrm{mL}\right)$ for L. plantarum Dad 13 and one log cycle for $S$. thermophilus Dad $11\left(10^{8} \mathrm{CFU} / \mathrm{mL}\right)$, respectively. The viable cell of freeze-dried L. plantarum Dad 13 and $S$. thermophilus Dad 11 were $7.57 \mathrm{x}$ $10^{10} \mathrm{CFU} / \mathrm{g}$ and $6.35 \times 10^{9} \mathrm{CFU} / \mathrm{g}$, respectively. The number of viable cells and $\mathrm{pH}$ of both fermented milk drink and yogurt products was relatively stable to $10^{7} \mathrm{CFU} / \mathrm{mL}$ and $10^{8} \mathrm{CFU} / \mathrm{mL}$, respectively during cold storage for four to six weeks. The sensory characteristics of the products were comparable to the ones using commercial starter cultures. It can be concluded that these indigenous starter cultures can be applied for the production of probiotic fermented milk.
\end{abstract}

\section{Keywords}

indigenous lactic acid bacteria, halal starter cultures, milk fermentation

\section{Introduction}

Lactic acid bacteria play an important role in many Indonesian fermented foods such as fermented fish [1,2], fermented meat [3], tempe production [4], and fermented buffalo milk [5]. The genus of Lactobacillus plays the most important role in Indonesian fermented foods, and L. plantarum has been found to be the most common species found in traditional Indonesian fermented food [6]. There are numerous application areas for the use of lactic acid bacteria in foods. The involvement of lactic acid bacteria in foods could be grouped into three different aspects, as starter cultures for producing fermented food, as bio-preservatives and as components for probiotic food. A combination of these three aspects is certainly possible, such as using probiotic strains that also have antimicrobial agents or as a starter culture. Lactic acid bacteria (LAB) are widely used as starter cultures in milk fermentation. There are various fermented milk products such as yogurt, Dahi, Bulgarian buttermilk, and "Caspian Sea yogurt" which require different starter cultures, either mixed cultures or a single culture $[7,8]$.

There are many fermented dairy products that contain probiotics. Probiotics can be introduced into the product at the end of fermentation time or in the initial time with the starter culture. The majority of products containing probiotics are dairy-based, that include yogurt, fermented milk beverage, and cheese. It has been reported that many lactic acid bacteria isolated from traditional fermented food fulfilled the 
basic requirements as probiotics [9]. To be able to give beneficial effects, probiotics must be able to survive during food processing and have the resistance against gastric acid, bile salt, and digesting enzyme before reaching the small intestine. In Indonesia, the market for fermented milk products develops significantly, especially for yogurt and fermented milk drink. Although numerous fermented milk products can be found in the market, the starter cultures that be used for the production of fermented milk are still imported.

Lactobacillus plantarum Dad 13 is an indigenous lactic acid bacteria isolated from traditional fermented buffalo milk in West Sumatera, Indonesia. Our previous research showed that L. plantarum Dad 13 had some functional properties, such as antimicrobial activity against pathogenic bacteria [10], antioxidant activity [11], and also probiotic characteristics [12]. This indigenous probiotic candidate showed good performance when applied to milk fermentation either as a single culture or mixed cultures at a laboratory scale [13].

There are many challenges and opportunities for the development of indigenous lactic acid bacteria as starter cultures for the fermented milk industry. Lactic acid bacteria are fastidious microorganisms which need exogenous sources of carbon, nitrogen, vitamins, minerals, and growth factors for their growth. Laboratory scale medium for the growth of lactic acid bacteria such as MRS broth cannot be used to develop starter culture for industrial scale, because it is too expensive for large scale fermentation. In addition, with a very high Muslim population in Indonesia, food industries also concern about halal materials for halal food, including halal media for starter culture preparation in fermented food products. Therefore, the aim of this research was to evaluate the production of indigenous lactic acid bacteria using natural halal materials media, preparation of starter culture and application of starter culture for production of fermented milk drink and yogurt in industrial scale.

\section{Materials and methods}

\subsection{Materials}

Lactobacillus plantarum Dad 13 and Streptococcus thermophilus Dad 11 which were used as starter cultures are the collection of Food and Nutrition Culture Collection (FNCC), Center for Food and Nutrition, Universitas Gadjah Mada, Yogyakarta, Indonesia. The cultures were stored in a mixture of $10 \%$ skim milk and $1 \%$ sucrose under $-20^{\circ} \mathrm{C}$. Batu variety pineapple as a source of crude bromelain, halal mince beef, and young coconut water was purchased from a local market. Mung bean sprout, tomatoes and sugar (Gulaku) were purchased from a local supermarket.

\subsection{Preparation of halal media}

Halal media consisted of halal meat peptone, sucrose, mung bean sprout extract, tomato extract, and young coconut water. Unskinned pineapples were cleaned and cut into small pieces and extracted the juice using a juicer. Halal meat peptone was prepared by hydrolyzes of halal mince beef with liquid crude bromelain $(1: 4 \mathrm{w} / \mathrm{v})$ at shaker water-bath at $50^{\circ} \mathrm{C}$ for $3 \mathrm{~h}$. To stop the reaction, the mixture was boiled at $\pm 90^{\circ} \mathrm{C}$ for 20 minutes and stood at room temperature. The mixture then was filtered using a double-layered cheesecloth. The liquid meat peptone then was stored at $-20^{\circ} \mathrm{C}$ until it is used.

Preparation of mung bean sprout extract was carried out by boiling of mung bean sprout with water for $2 \mathrm{~h}$ and then followed by filtration using a double-layered cheesecloth to get the mung bean sprout extract. Cleaned tomatoes were cut into small pieces and sterilized in an autoclave (Hiramaya, Japan) at $121^{\circ} \mathrm{C}$ for 20 minutes. The liquid released was collected and filtered using a double-layered cheesecloth. All the components were stored at $-20^{\circ} \mathrm{C}$. The halal medium was prepared by a mixture of meat peptone $(25 \%)$, sucrose (3\%), mung bean sprout extract (40\%), tomato extract (2\%) and fresh young coconut water (30\%).

\subsection{Preparation of starter cultures}

Starter culture for production of fermented milk drink was L. plantarum Dad 13 while starter cultures for plain yogurt fermentation were L. plantarum Dad 13 and S. thermophilus Dad 11. The isolates were growth in halal media for $24 \mathrm{~h}$ at $30^{\circ} \mathrm{C}$. Starter cultures were prepared as frozen and freeze-dried cultures. The culture suspension was centrifuged using a refrigerated centrifuge (Beckman J-6B, Germany) to harvest the cell. The cell pellets were re-suspension using the liquid of $10 \%$ skim milk and $1 \%$ sucrose mixture. 
Every pellet from one Liter growth media was resuspended into $50 \mathrm{~mL}$ of $10 \%$ skim milk and $1 \%$ sucrose mixture and then were stored at the frozen condition.

To produce freeze-dried starter culture, pellets that be re-suspended in $10 \%$ skim milk and $1 \%$ sucrose mixture were frozen for overnight $\left(\right.$ at $-20^{\circ} \mathrm{C}$ ) and followed by freeze-dried cultures for $3 \mathrm{~h}$. The viable cells were enumerated using dilution and pour plate method in MRA agar with $\mathrm{CaCO}_{3}$. The freeze-dried starter cultures were examined their ability to grow in $10 \%$ skim milk at $37^{\circ} \mathrm{C}$ for $24 \mathrm{~h}$.

\subsection{Fermentation of milk using indigenous starter cultures}

Indigenous lactic acid bacteria were used as a starter culture for the production of fermented drink and plain yogurt. Freeze-dried single culture of L. plantarum Dad 13 was examined its performance as a starter culture for the production of fermented milk drink in industrial scale. The viability of freeze-dried cells was evaluated for 60 days stored at room temperature. Freeze-dried starter culture was prepared for $12 \mathrm{~L}$ growth media and then harvested, frozen and freeze-dried for 3 days to get starter culture powder as those described in the previous section. The starter culture powder was sent to PT Yummy Food Utama, a fermented milk industry, and used as a starter culture for production of fermented milk drink (Yofit) in $1000 \mathrm{~L}$ fermenter. Fermentation, product formulation, and packaging were done by the Industry. The products were examined the viable cell and $\mathrm{pH}$ during storage. Sensory evaluation was carried out using a hedonic test for fermented milk drink products (plain, strawberry-flavor, and blueberry flavor fermented milk drink products) prepared using indigenous starter culture and commercial starter cultures. Thirtyone panelists were asked to give score for overall performance of six fermented milk drink products with seven points hedonic scale: extremely like very much (1); like very much (2); like moderately (3); neutral (4); dislike moderately (5); dislike very much (6); extremely dislike (7).

For the production of plain yogurt, each of the frozen starter culture of L. plantarum Dad 13 and $S$. thermophilus Dad 11 was activated in $10 \%$ skim milk and incubated at $30^{\circ} \mathrm{C}$ for $18 \mathrm{~h}$. Starter cultures were prepared by inoculation of each culture $(1 \% \mathrm{v} / \mathrm{v})$ into $6 \times 1 \mathrm{~L} 10 \%$ skim-milk and then incubated at $30^{\circ} \mathrm{C}$ for $18 \mathrm{~h}$. These starter cultures were used for the production of plain yogurt in PT Yummy Food Utama. Plain yogurt products were tested for viable cells and pH for 6 weeks. The cell viability of total lactic acid bacteria and L. plantarum were examined using MRS agar and LPSM agar media respectively.

\section{Results and discussion}

\subsection{Development of indigenous starter cultures}

Lactobacillus plantarum Dad13 and S. thermophilus Dad 11 were grown in culture media to get enough amount of starter cultures for industrial scale. The population of L. plantarum Dad 13 and S. thermophilus Dad 11 during starter culture preparation were presented in Table 1 . After incubation at $30^{\circ} \mathrm{C}$ for $24 \mathrm{~h}$, the population of L. plantarum Dad 13 and S. thermophilus Dad 11 increased two and one log cycle respectively to $1.90 \times 10^{9} \mathrm{CFU} / \mathrm{mL}$ and $2.52 \times 10^{8} \mathrm{CFU} / \mathrm{mL}$. The lower growth of $S$. thermophilus Dad 11 was due to the low temperature of incubation. The freeze-dried cultures obtained were $10.58 \log \mathrm{CFU} / \mathrm{g}$ and $9.80 \mathrm{CFU} / \mathrm{g}$ for L. plantarum Dad 13 and S. thermophilus Dad 11 respectively.

Microorganisms should be cultured or grown in a suitable medium in order to get a sufficient number of viable cells. MRS is a suitable medium for lactic acid bacteria. Commercial MRS contains peptone, meat extract (Lab Lemco), and yeast extract as nitrogen sources [14]. Usually, the most expensive component of microbial growth media is the nitrogen source. Here, we developed halal meat peptone by hydrolyzed of halal meat using crude bromelain from pineapple juice. Based on the soluble nitrogen, the degree of hydrolysis of meat protein by crude bromelain was more than $95 \%$ after $3 \mathrm{~h}$ at $50^{\circ} \mathrm{C}$ [15]. Natural halal media were used for the production of lactic acid bacteria, which consisted of halal meat peptone, sucrose, mung bean sprout extract, tomato extract and young coconut water. Lactic acid bacteria are fastidious microorganisms, which have an absolute need for some amino acids. It has been reported that isoleucine, leucine, and valine were essential for the growth of L. plantarum NCFB 1752 and L. plantarum NC8 [16]. It has been found that besides those three amino acids, L. plantarum ATCC 8014 absolutely required Lglutamic acids, L-methionine, L-phenylalanine, and L-tryptophan [17]. Therefore, those amino acids should be provided in the growth media. Here, halal meat peptone produced by hydrolysis of minced beef by crude bromelain provided those amino acids. Vitamins, minerals, and growth factors were provided by 
germinated mung bean extract, young coconut water and tomato extract. Coconut water also contains glucose and sucrose as carbon sources for lactic acid bacteria [18]. Tomato extract contains some growth factors for lactic acid bacteria [19].

Starter cultures should be healthy, active and sufficient amount before introducing to the fermentation medium. Initial starter culture of $6.88 \mathrm{log} \mathrm{CFU} / \mathrm{mL}$ was considered to be enough for fermentation of skim milk in laboratory-scale which increased the cell population to about one log cycle (Table 2). It has been reported that the optimum temperatures for cell growth of L. plantarum Dad 13 and acid production were $30^{\circ} \mathrm{C}$ and $37^{\circ} \mathrm{C}$ respectively [13]. Therefore, incubation temperature for cell propagation was $30^{\circ} \mathrm{C}$, meanwhile fermentation temperature was $37^{\circ} \mathrm{C}$.

Table 1 The growth of L. plantarum Dad 13 and S. thermophilus Dad 11 in halal media and their viability during the preparation of freeze-dried cultures

\begin{tabular}{lcc}
\hline \multicolumn{1}{c}{ Step } & L. Yummy Dad 13 & S. thermophilus Dad 11 \\
\hline Initial (CFU/mL) & $7.34 \pm 6.92$ & $7.26 \pm 5.98$ \\
After incubation (CFU/mL) & $9.28 \pm 8.92$ & $8.40 \pm 7.34$ \\
After harvesting and re-suspension in cryo- & $10.58 \pm 10.22$ & $9.70 \pm 8.64$ \\
protectant (CFU/mL) & & \\
After freezing (CFU/mL) & $10.57 \pm 10.24$ & $8.69 \pm 7.89$ \\
After freeze drying (CFU/g) & $10.57 \pm 9.85$ & $9.80 \pm 9.34$ \\
\hline
\end{tabular}

Table 2 The growth of freeze-dried starter cultures in skim-milk at $37^{\circ} \mathrm{C}$ for 24 hours

\begin{tabular}{ccc}
\hline \multirow{2}{*}{$\begin{array}{c}\text { Fermentation } \\
\text { Time }(\mathrm{h})\end{array}$} & \multicolumn{2}{c}{ Cell amount $(\log \mathrm{CFU} / \mathrm{mL})$} \\
\cline { 2 - 3 } & L. plantarum Dad 13 & S. thermophilus Dad 11 \\
\hline 0 & $6.88 \pm 0.04$ & $6.89 \pm 0.02$ \\
8 & $6.91 \pm 0.05$ & $7.15 \pm 0.11$ \\
12 & $7.30 \pm 0.24$ & $7.32 \pm 0.01$ \\
16 & $7.42 \pm 0.12$ & $7.41 \pm 0.03$ \\
20 & $7.52 \pm 0.04$ & $7.75 \pm 0.10$ \\
24 & $7.62 \pm 0.09$ & $7.93 \pm 0.01$ \\
& $7.81 \pm 0.13$ & $8.05 \pm 0.03$ \\
\hline
\end{tabular}

\subsection{Application of indigenous starter cultures for production of the large scale of fermented milk drink and yogurt}

Freeze-dried powder of L. plantarum Dad 13 was used as a starter culture for the production of fermented milk drink. Production of starter culture was carried in $12 \mathrm{~L}$ growth media. After incubation at $30^{\circ} \mathrm{C}$ for 24 hours, the viable cells were $2.28 \times 10^{9} \mathrm{CFU} / \mathrm{ml}$ or a total of $2.4 \times 10^{13} \mathrm{CFU}$. After freeze-drying, the freezedried powder obtained was $72.3 \mathrm{~g}$ with the total viable cells of $5.60 \times 10^{12} \mathrm{CFU}$. The reduction of the viable cells during freezing and freeze-drying was less than one log cycle. Freezing and freeze-drying can significantly affect cell viability. Here we used a mixture of $10 \%$ skim milk and $1 \%$ sucrose. All of these freeze-dried starter cultures were immediately sent to the fermented milk industry and applied for the production of fermented milk drink. The freeze-dried starter culture of L. plantarum Dad 13 was quite stable during storage at vacuum-sealed aluminum foil at room temperature (Table 3). For the application of dairy probiotic, skim milk is commonly used as a cryoprotectant. Disaccharides such as sucrose, lactose, and trehalose also can be used as cryoprotectants. It has been reported that among sucrose, trehalose, and sorbitol, sucrose at $5 \%$ and $1 \%$ were the best protection to the cell of L. plantarum NCIMB 8826 whereas sorbitol was the least [20].

Table 3 Cell viability of freeze-dried L. plantarum Dad 13 during storage at room temperature

\begin{tabular}{cc}
\hline Storage time & Viable cell $(\log \mathrm{CFU} / \mathrm{g})$ \\
\hline Initial & $10.88 \pm 9.86$ \\
30 days & $10.48 \pm 9.98$ \\
60 days & $10.16 \pm 9.72$ \\
\hline
\end{tabular}

Fermented milk drink was produced using a freeze-dried starter culture of L. plantarum Dad 13 with three different flavors namely plain, strawberry and blueberry fermented milk drink. The viable cells of $L$. 
plantarum Dad 13 in the fermented milk drink were quite stable during storage in the range of $1.47 \times 10^{7}$ $\mathrm{CFU} / \mathrm{mL}$ to $5.80 \times 10^{7} \mathrm{CFU} / \mathrm{mL}$ with $\mathrm{pH}$ ranged from $4.05-4.14$ (Table 4). These values were similar to the $\mathrm{pH}$ of the product produced by commercial starter cultures (4.05-4.09). Since the starter culture is a probiotic candidate, the amount of the viable cells in the product is very important. Yakult contains $6.5 \mathrm{x}$ $10^{9} \mathrm{CFU}$ L.casei Shirot strain per bottle. Consumption of L. casei Shirota strain fermented milk by 26 healthy Indonesian people showed markedly increase the population of L. casei Shirota strain in the feces to 6-7log CFU/g [21]. The volume of this fermented milk drink per bottle was $180 \mathrm{~mL}$. Therefore, the viable cell of probiotic in one bottle is $1.04 \times 10^{10} \mathrm{CFU}$. Consumption of L. plantarum Dad 13 containing fermented milk drink by 30 healthy Indonesian people showed a significant increase in the population of L. plantarum in the feces from about $3 \log \mathrm{CFU} / \mathrm{g}$ to $7 \log \mathrm{CFU} / \mathrm{g}$ [12]. It means that this indigenous probiotic not only can be used as a starter culture for fermented milk but also survive during storage in still alive in the gastrointestinal tract.

Table $4 \mathrm{pH}$ and viable cell of fermented milk drink using indigenous starter culture during storage

\begin{tabular}{ccccccc}
\hline $\begin{array}{c}\text { Storage time } \\
\text { at } 4{ }^{\circ} \mathrm{C}\end{array}$ & \multicolumn{2}{c}{ Plain fermented milk drink } & \multicolumn{2}{c}{$\begin{array}{c}\text { Strawberry fermented milk } \\
\text { drink }\end{array}$} & \multicolumn{2}{c}{ Blueberry fermented milk drink } \\
\cline { 2 - 7 } & $\mathrm{pH}$ & Cell CFU $/ \mathrm{mL}$ & $\mathrm{pH}$ & Cell CFU/ml & $\mathrm{pH}$ & Cell CFU $/ \mathrm{ml}$ \\
\hline 2 weeks & $4.05 \pm 0.07$ & $7.17 \pm 6.65$ & $4.05 \pm 0.05$ & $7.74 \pm 6.60$ & $4.07 \pm 0.08$ & $7.61 \pm 6.76$ \\
3 weeks & $4.09 \pm 0.07$ & $7.25 \pm 6.57$ & $4.08 \pm 0.06$ & $7.76 \pm 6.82$ & $4.09 \pm 0.05$ & $7.71 \pm 6.51$ \\
4 weeks & $4.11 \pm 0.05$ & $7.56 \pm 6.40$ & $4.11 \pm 0.07$ & $7.59 \pm 6.58$ & $4.14 \pm 0.05$ & $7.60 \pm 6.79$ \\
\hline
\end{tabular}

Hedonic test for fermented milk drink with three different flavors using L. plantarum Dad 13 and commercial starter cultures is presented in Table 5. All fermented milk drink produced either using indigenous or commercial starter cultures were packed in the same plastic bottle as the one produced commercially in the market. All the panelists were the students who familiar with fermented milk products. Based on the hedonic test, panelists gave the value in the range from "like very much" to "neutral" with the average like moderately. There was not any different preference for the flavor of fermented milk drink. It means that fermented milk drink produced using the culture of $L$. plantarum Dad 13 was comparable to the one produced using the imported commercial starter culture. The home-use test was carried out in Yogyakarta involving 100 family members to get the family perception of fermented milk drink produced using our indigenous lactic acid bacteria [22]. The overall perception of panelists to peach-flavored fermented milk drink and strawberry-flavored fermented milk drink was neutral.

Table 5 Hedonic test of fermented milk drink using commercial starter cultures and indigenous starter culture

\begin{tabular}{lcc}
\hline \multicolumn{1}{c}{ Fermented milk drink } & \multicolumn{2}{c}{ Starter culture } \\
\cline { 2 - 3 } & Commercials & L. plantarum Dad 13 \\
\hline Plain fermented milk drink & $2.94 \pm 1.09$ & $2.90 \pm 1.11$ \\
Strawberry fermented milk drink & $3.03 \pm 1.02$ & $2.84 \pm 1.13$ \\
Blueberry fermented milk drink & $2.90 \pm 1.22$ & $2.74 \pm 1.12$ \\
\hline
\end{tabular}

Plain set yogurt was produced using liquid starter cultures of $6 \mathrm{~L}$ of L. plantarum Dad 13 and $6 \mathrm{~L} S$. thermophilus Dad 11 in the industry using $1000 \mathrm{~L}$ fermenter. The plain yogurt consisted of only milk and starter cultures without the addition of any ingredients. The product was smooth with compact curd. The industry sets the self-life of 6 weeks for the product. The viable cell and $\mathrm{pH}$ of the plain yogurt were monitored until the end of the self-life time (Table 6). Total lactic acid bacteria and L. plantarum were $10^{8}$ $\mathrm{CFU} / \mathrm{mL}$ and $10^{7} \mathrm{CFU} / \mathrm{mL}$ respectively. It seems that that $S$. thermophilus Dad 11 grew faster than $L$. plantarum Dad 13. Physically yogurt produced using indigenous starter cultures was quite stable with good curd formation and syneresis only about $3 \%$ at the end of self-life time. During yogurt fermentation, lactic acid bacteria consumed carbon source for their growth and metabolic activity. The $\mathrm{pH}$ gradually decreased as the acid increased. When the $\mathrm{pH}$ drops to the casein isoelectric points, the colloidal dispersion of casein micelles collapse, and then acid casein precipitates forming curd [23]. The acidification process results in the formation of a three-dimensional network consisting of clusters and casein chains [24]. It could be that the production of acid by these two starter cultures was high enough resulted in the high three-dimensional network formation and a quite strong curd formation. 
Table 6 Cell viability and $\mathrm{pH}$ of plain set yogurt during storage at $4^{\circ} \mathrm{C}$

\begin{tabular}{cccc}
\hline $\begin{array}{c}\text { Storage time } \\
\text { (week) }\end{array}$ & $\begin{array}{c}\text { Total lactic acid bacteria } \\
\text { (CFU/mL) }\end{array}$ & $\begin{array}{c}\text { L. plantarum } \\
\text { (CFU/mL) }\end{array}$ & $\mathrm{pH}$ \\
\hline 2 & $8.80 \pm 7.39$ & $7.52 \pm 6.63$ & $4.30 \pm 0.08$ \\
3 & $8.71 \pm 7.51$ & $7.53 \pm 6.49$ & $4.44 \pm 0.10$ \\
4 & $8.36 \pm 7.69$ & $7.13 \pm 6.77$ & $4.22 \pm 0.04$ \\
5 & $8.19 \pm 7.79$ & $7.17 \pm 6.63$ & $4.06 \pm 0.05$ \\
6 & $8.24 \pm 7.65$ & $7.14 \pm 6.54$ & $4.02 \pm 0.05$ \\
\hline
\end{tabular}

\section{Conclusions}

Preparation of freeze-dried lactic acid bacteria starter cultures has been developed for milk fermentation. Freeze-dried L. plantarum Dad 13 and S. thermophilus Dad 11 could grow well in 10\% skim-milk. The indigenous probiotic of L. plantarum Dad 13 can be used as a single starter culture or mixed cultures with S. thermophilus Dad 11 for large scale production of fermented milk. The $\mathrm{pH}$ and viable cells in fermented milk produced by L. plantarum Dad 13 starter culture were quite stable in the range of 4.05-4.11 and $10^{7}$ $\mathrm{CFU} / \mathrm{mL}$ respectively. The $\mathrm{pH}$ and viable cells of plain yogurt produced using L. plantarum Dad 13 and $S$. thermophilus Dad11 were also quite stable until the self-lifetime of 6 weeks with total lactic acid bacteria and L. plantarum of $10^{8} \mathrm{CFU} / \mathrm{mL}$ and $10^{7} \mathrm{CFU} / \mathrm{mL}$ respectively. Based on the hedonic test, fermented milk produced using indigenous culture was comparable to the one using commercial starter cultures.

Acknowledgement: The authors would like to thank the Ministry of Research, Technology and Higher Education, the Republic of Indonesia for their financial support through "PUPT" research project year 2016-2017.

\section{References}

1. Lawalata, H. J., Sembiring, L., Rahayu, E.S.: Molecular identification of lactic acid bacteria producing antimicrobial agents from bakasang, an Indonesian traditional fermented fish product. Indonesian Journal of Biotechnology, 16(2):93-99 (2011)

2. Wikandari, P.W., Suparmo, Marsono. Y., Rahayu, E.S.: Potency of lactic acid bacteria isolated from bekasam as Angiotension Converting Enzyme Inhibitor produce in bekasam fermentation like product. Agritech, 32(3):258-264 (2012)

3. Pramono, Y. B., Rahayu, E.S., Suparmo, Utami, T.: Isolation and identification of lactic acid bacteria in meat petis fermentation. Journal Pengembangan Peternakan Tropis, 33(4):319-323 (2008)

4. Pisol, B., Abdullah, N., Khalil, K.A., and Nuraida, L.: Antimicrobial activity of lactic acid bacteria isolated from different stages of soybean tempe production. Australian Journal of Basic and Applied Science, 9(28):230-234 (2015)

5. Purwandhani, S.N., Utami, T., Milati R and Rahayu, E.S.: Isolation, characterization and screening of folate-producing bacteria from traditional fermented food (dadih). International Food Research Journal, 25(2):566-572 (2018)

6. Rahayu, E.S.: Lactic acid bacteria in fermented foods o Indonesian origin. Agritech, 23(2):75-84 (2003)

7. Tamime, A. Y., and Robinson: Yoghurt Science and Technology. Cambridge: Woodhead Publishing Ltd. (2000)

8. Ishida, T., Yokota, A., Umezawa, Y., Toda, T., and Yamada, K.: Identification and characterization of Lactococcal and Acetobacter strains from traditional Caucasian fermented milk. Journal of Nutritional Science and Vitaminology, 51:187-193 (2005)

9. Nuraida, L.: A review: health promoting lactic acid bacteria in traditional Indonesian fermented foods. Food Science and Human Wellness, 4:46-55 (2015)

10. Sumaryati, B. T., Utami, T., Suparmo: Effect of infection of Escherichia coli and addition of Lactobacillus plantarum Dad 13 to fecal microbiota of Wistar rat. Agritech, 29(1):165-170 (2009)

11. Fitrotin., U., Utami, T., Hastuti, P., and Santosa, U.: Antioxidant properties of fermented sesame milk using Lactobacillus plantarum Dad 13. International Research Journal of Biological Sciences, $4(6): 56-61(2015)$ 
12. Endang S Rahayu, Muhammad N Cahyanto, Mariyatun, Martinus-Agus Sarwoko, Pri Haryono, Linda Windiarti, Joko Sutriyanto, Istiti Kandarina, Sri Nurfiani, Eni Zulaichah, and Tyas Utami: Effect of consumption of fermented milk containing indigenous probiotic Lactobacillus plantarum Dad 13 on fecal microbiota of healthy Indonesian volunteers. Journal of Probiotic and Prebiotic, 11(2):91$98(2016)$

13. Wardani, S.K., Cahyanto, M.N., Rahayu, E.S., and Utami, T.: The effect of incubation temperature on cell growth, acid production and curd formation during milk fermentation by Lactobacillus plantarum Dad 13. International Food Research Journal 24(3):921-926 (2017)

14. Bridson, E. Y.: The Oxoid Manual $8^{\text {th }}$ edition. England, Oxford Limited, Hampsire (1998)

15. Utami, T., Kusuma, E.N., Satiti, R. Rahayu, E.S, and Cahyanto, M.N.: Hydrolysis of meat and soybean proteins using crude bromelain to produce halal peptone as a complex nitrogen source for the growth of lactic acid bacteria. International Food Research Journal, 26(1):117-122 (2019)

16. Moretro, T., Hagen, B.F and Axelsson, L.: A new, completely defined medium for meat lactobacilli. Journal of Applied Microbiology, 85:715-722 (1998)

17. Morishita, T., Deguchi, Y., Yajima, M., Sakurai, T and Yura, T.: Multiple nutritional requirements of lactobacilli: Genetic lesions affecting amino acids byisynthetic pathways. Journal of Bacteriology, 148(1):64-71 (1981)

18. Yong, J. W. H., Ge, L., Ng, Y.F., and Tan, S.N.: Review: The chemical composition and biological properties of coconut (Cocos nucifera L.) water. Molecules, 14:5144-5161 (2009)

19. Ray, B.: Fundamental of food microbiology. Boca Raton, CRC Press (1996)

20. Siaterlis, A., Deepika, G and Charalampopoulos, D.: Effect of culture medium and cryoprotectants on the growth and survival of probiotic lactobacilli during free drying. Letters in Applied Microbiology 48:295-301 (2009)

21. Tyas Utami, Muhammad Nur Cahyanto, Mohammad Jufrie, Endang Sutriswati Rahayu: Recovery of Lactobacillus casei strain Shirota from the intestine of healthy Indonesian volunteers after intake of fermented milk and its impact on the enterobacteriaceae faecal microbiota. International Journal of Probiotics and Prebiotics, vol 10 No 2/3:77-84 (2015)

22. Fathyah Hanum Paungkaningtyas, Mariyatun, Rafli Zulfa Kamil, Ryan Haryo Setyawan, Pratama Nur Hasan, Devin Wiryohanjoyo, Sri Nurfiani, Eni Zulaichac, Indyah S Utami, Tyas Utami., Endang S Rahayu: Sensory evaluation of yogurt-like set and yogurt-like drink produced by indigenous probiotic strains for market test. Indonesian Food and Nutrition Progress 15(2):1-10 (2008)

23. Vedamuthu, E. R.: Strter cultures for yogurt and fermented milks. In Chandan, R.C. (ed.). Manufacturing yogurt and fermented milks. p89-115. Oxford, Blackwell Publishing (2006)

24. Lee, W. J and Lucey, J.: Formation and physical properties of yogurt. Asian-Australasian Journal of Animal Science, 23(9):1127-1136 (2010) 